\title{
$\sum[6]$ \\ Transformation Management Islamic Institute Becomes a World-Class Institute: Strategy Planning and Implementation
}

\author{
Yetty Faridatul Ulfah \\ Institut Islam Mamba'ul 'Ulum Surakarta, Jl. Sadewa No.14, Central Java, Indonesia \\ yettyfaridatululfah@iimsurakarta.ac.id
}

\begin{abstract}
One of the fundamental challenges for education in the era of globalization is that educational institutions must make changes or transformations. This study aims to analyze 1) the transformation of the management of IIM Surakarta into a World-Class Islamic Institute, 2) the strategy in the strategic plan of IIM Surakarta, 3) the implementation of the strategic plan IIM Surakarta. This research approach is descriptive qualitative by applying the case study method at IIM Surakarta. Data were collected using observation, in-depth interviews, and document studies. The results of this study reveal that. 1) The management aspect of the transformation of IIM Surakarta into a World-Class Islamic Institute includes planning, organizing, implementing and evaluating; 2) Strategy is made by conducting a SWOT analysis, and 3) Implementation of the Strategic Plan of IIM Surakarta includes two things, namely setting goals and preparing annual strategic programs.
\end{abstract}

Salah satu tantangan nyata bagi pendidikan di era globalisasi adalah lembaga pendidikan harus mampu melakukan perubahan atau transformasi. Penelitian ini bertujuan untuk menganalisis 1) transformasi manajemen IIM Surakarta menjadi World Class Islamic Institute, 2) strategi dalam renstra IIM Surakarta, 3) implementasi renstra IIM Surakarta. Pendekatan penelitian ini adalah deskriptif kualitatif dengan menerapkan metode studi kasus yang berlokasi di IIM Surakarta. Data dikumpulkan dengan teknik observasi, wawancara mendalam, dan studi dokumen. Hasil penelitian ini mengungkapkan bahwa. 1) Aspek manajemen transformasi IIM Surakarta menjadi World Class Islamic Institute meliputi perencanaan, pengorganisasian, pelaksanaan dan evaluasi, 2) Strategi dibuat dengan melakukan analisis SWOT, 3) Pelaksanaan Renstra IIM Surakarta meliputi dua hal, yaitu penetapan tujuan dan penyusunan program strategis tahunan.

Keywords: Transformation Management, World Class Islamic Institute, Strategy Implementation.

Received: October 2, 2021; Revised: November 3, 2021; Accepted: December 22, 2021

\section{INTRODUCTION}

Managing transformation or direction of change at the organizational level has been an essential aspect of successful change implementation programs in modern 
organizations. Therefore, according to Hassan, corporate transformation management facilitates the change process by modifying strategies, structures, and procedures (Hassan, 2018). Employees in an organization are significant players in the change process. Their response to change is a determining factor for the success or failure of a change initiative.

The conceptual framework of the management of change as a process includes (1) recognition and initiation, (2) diagnosis, (3) planning, (4) clear objectives, (5) implementation, (6) open communication, (7) sustaining change, (8) leading and managing people's problems, and (9) and constant attention paid to feedback from workers. In addition, the changes that organizations face today must involve new technologies or communication systems (Hayes, 2018). If an organization wants to keep up with the latest industry practices, the leaders need to ensure that employees are continuously trained on the new technologies they will be using (Johnson, 2019).

In the context of the education industry, management of change is a systematic process of planning, organising, mobilizing and controlling carried out by institutional managers to shift from current conditions to standard conditions by empowering organizational resources to achieve shared goals that have been set effectively and efficiently (Darma \& Banurea, 2019).

Education in the era of globalization demanding the development of information technology provides new demands and challenges for educational institutions themselves. One of the fundamental challenges for education in globalization is that educational institutions must make changes or transformations (Ali Mufron, Ikhwan, Syuhada, \& Ridlowi, 2021). According to Wijaya et al. the transformation of learning in the 21 st century requires human resources possessing superior quality, produced by the education industry that is professionally managed well (Etistika Yuni Wijaya, Sudjimat, \& Nyoto, 2016). These new demands require various innovations in thinking, drafting and maturation of concepts and movements. The point is that a new paradigm is needed to face new challenges where these challenges require an innovative thought process to produce quality and quality outputs to compete in an all open world.

According to Mawardi, the transformation of higher education institutions is more focused on physical and mental changes in the education system due to the interaction of scientific developments and new findings accompanying the pace of globalization (Mawardi, 2017). This institutional transformation includes aligning or redesigning strategies, structures, techniques, and relationships between stakeholders, staff, capabilities, leadership styles, and shared values. The transformation process is expected to awaken the role of higher education institutions to play an optimal position in creating academic excellence for education, industrial relevance, contribution to new knowledge, and empowerment (Chaer, Rochmah, \& Sukatin, 2021).

Thus, it can be concluded that a world-class university or institute means possessing excellence in various matters which should have a reputation in terms of teaching, learning, quality human resources, scientific publications and being able to compete on a local, national, and international level.

Syahrul states that higher education institutions must consider two crucial things to prepare for change, namely in terms of hardware and software (Syahrul, 2016). In this case, hardware is the infrastructure owned by the institution. Meanwhile, the software 
includes policies, legal umbrellas and implementing rules. Significantly, the software that can be analyzed to determine the preparation for institutional transformation is the Strategic Plan and Operational Plan document.

Strategic and operational plans are based on the scientific truth of reasoning, fairness, benefits, policies, responsibility and affordability. According to Mawardi, the two projects form a development strategy (Mawardi, 2017). Higher education institutions can accelerate and be conducive by integrating all sources and expertise in obtaining various targets in the institution's medium-term and long-term plans.

One form of development in Islamic higher education institutions in the current era of globalization is the World Class Islamic Institute (WCII) and the World Class Islamic University (WCIU), or Islamic institutes and world-class Islamic universities. Based on empirical data from Webometrics 2020 investigating the ranking of universities globally, several Islamic higher education institutions in Indonesia have a view or vision to become a world-class university or institute in the last decade.

In preparing for the World Class Islamic Institute (WCII) and World Class Islamic University (WCIU), a higher education institution must have a strategic intent where institutional transformation is no longer at the organizational development stage but is more complex. Mufron claims that Islamic higher education institutions, in their efforts to become WCIU, must lay a strong foundation through developing the character of educators and education staff possessing academic ethics with rational, objective and normative characteristics (A Mufron, 2021). Academic ethics must be a fundamental element of morality in social, economic, political, cultural, scientific, and technological developments (Anwar, 2021).

The term of World Class Islamic Institute or World Class Islamic Universities, translated by Mastuki, is necessary, namely a single way for Islamic higher institutions to survive and compete amid globalization (Mastuki, 2015). World-Class Islamic University can also be interpreted as ranking, assessment, and recognition at the international level on Islamic campuses or universities in several countries.

Meanwhile, based on a study conducted by Levin et al. that the indicators for a worldclass university barometer at the international level are in the areas of 1) excellent and quality research, 2) unlimited academics and a pleasant intellectual atmosphere, 3) strong self-management, 4) supporting facilities and infrastructure and financing, 5) diverse knowledge, 6) internalization program, 7) democratic leadership style, 8) technology used optimally, 9) adequate learning quality, 10) relations with the community, 11) cooperation and collaboration in the internal environment of the institution (Levin, Jeong, \& Ou, 2006).

Thus, it can be concluded that a higher education institution with the label WorldClass Islamic Institute is an Islamic higher education institution having a good reputation in the international arena in the fields of learning and teaching, quality human resources, publication of scientific works, and the value of competitiveness. Several famous ranking institutions at the higher education level in Indonesia, including Times Higher Education Supplement (THES), Webometrics, and Shanghai Jiao Tong University (SJTU).

The Mamba'ul 'Ulum Islamic Institute (IIM) of Surakarta is one of the Islamic higher education institutes under Kopertais in the Central Java region, transforming a better, superior and competent Islamic educational institution ultimately leading to the 
realization of the World Class Islamic Institute. IIM has three faculties, five undergraduate study programs, and one diploma study program: Syari'ah Faculty encompassing two study programs; Ahwal Al Syakhshiyah (AS) and Sharia Banking (PBS) Diploma. The Tarbiyah Faculty consists of Madrasah Ibtidaiyah Teacher Education (PGMI) and Islamic Religious Education (PAI). Meanwhile, Da'wah Faculty includes Da'wah Management (MD) and Islamic Broadcasting Communication (KPI).

The strategic plan of IIM Surakarta becomes the primary reference or guidance for all Institute leaders in making and mapping the resources needed to carry out the planned program of activities for all teaching staff, academic staff and students. The main points of development of the Mamba'ul 'Ulum (IIM) Surakarta Islamic Institute in 2020-2024 describes the long-term development direction of the Institute. There are 3 (three) development targets in the major product, derived from a general policy for growth advice for each period.

In the end, it can be concluded that transformation or change must happen in higher education institutions to maintain the existence of institutions in this competitive era (Ilyasin, 2020). Therefore, management or management of these changes is needed based on the objectives. This means that the control of change concept for higher education must be implemented appropriately to realize the goals of a better and more competitive institution, namely the World Class Islamic Institute.

Several previous studies have examined the transformation management of higher education institutions by analysing their strategic plans and operational plans (Ikhwan, Biantoro, \& Rohmad, 2019). Still, those that lead to readiness for world-class Islamic institutes and the change process have not been studied empirically significantly. Therefore, this study attempts to describe 1) the management of the transformation of IIM Surakarta to a World-Class Islamic Institute, 2) the strategy in strategic planning of IIM Surakarta, and 3) the implementation of the strategic planning of IIM Surakarta.

\section{METHOD}

This research is a study that applies a qualitative descriptive research approach with a case study method where an in-depth exploration is carried out related to an activity or event (Indrawan, R., \& Yaniawati, 2017). This research was conducted at the Islamic Institute of Mamba'ul 'Ulum Surakarta. Data collection techniques were obtained by observation, in-depth interviews with purposive sampling and document studies (Sukmadinata, N, 2020). The word was to observe campus activities or activities that lead to change management. Interviews were conducted with people who have direct knowledge authority in managing change at IIM Surakarta, including the Rector and the Vice-Rector of IIM Surakarta, Head of Study Program, and several IIM lecturers. The document analyzed relates to the focus of the research, namely the Strategic Plan of IIM Surakarta in 2020-2024. The data analysis technique was an interactive model analysis by Miles and Huberman, consisting of data collection, data reduction, data presentation, and concluding (Ikhwan, 2021). 


\section{RESULT AND DISCUSSION}

\section{Management of transformation of IIM Surakarta into a World-Class Islamic Institute}

Management aspects of the transformation of IIM Surakarta to a World-Class Islamic Institute include 1) Planning, 2) Organizing, 3) Actuating, and 4) Evaluating. These aspects will be applied to the institute and all study programs at IIM Surakarta.

Institutionally, IIM Surakarta conducts transformation to lead to the development of better Islamic universities, the growth in both quality and quantity. The first transformation that the IIM plans is to plan to re-accreditation of study programs in the rank $\mathrm{C}$, and it also targets the institution and all study programs to achieve level A of accreditation by first evaluating all the potentials that exist in the institution. The activity is carried out by the Quality Assurance Institute of IIM Surakarta to determine whether each study program is running well according to the goals and visions, and missions previously planned.

The evaluation carried out by LPM also aims to determine whether each study program at IIM Surakarta has met the nine accreditation criteria according to the National Accreditation Board for Higher Education (BAN-PT), which consists of 1) vision, mission, goals and strategies, 2) governance civil service, governance, and cooperation, 3) students, 4) human resources, 5) finance, facilities and infrastructure, 6) education, 7) research, 8) community service, and 9) the outcomes and achievements of Tridharma (Majelis Akreditasi BAN-PT, 2019). Thus, the institution and all study programs at IIM Surakarta are expected to get a minimum rank B of accreditation.

In the learning process, the transformation is carried out in terms of the implementation of an online learning system, considering that during the past year, the world was in a state of the COVID-19 pandemic, where according to the mandate of the Ministry of Education and Culture of the Republic of Indonesia, it was required to conduct online learning. However, the change from face-to-face learning to an online model at IIM Surakarta requires a process and adjustment because not all lecturers master technology well. The campus in this process has slowly and surely provided direction and training for lecturers who experience difficulties in using technology for the learning process.

In the guidance stage of thesis writing and thesis examination implementation, students also have a transformation. The campus carries out monitoring or supervision to students writing thesis every month. In addition, in the performance of the exam, if in the past the exam was carried out by students by visiting the examining board one by one, now the thesis exam is carried out simultaneously by bringing together the examinees directly together with the four examiners; Chairman, Secretary, Examiner 1 and Examiner 2.

In the field of research and community service, IIM is also transforming to produce more scientific works by lecturers and students. This is carried out by providing research assistance provided by the campus to lecturers and students to encourage them to be more productive in writing scientific papers and community service. It is hoped that the written product will be registered by law. In addition, in the end, the output of the research can be published both at the national level (accredited by 
Scimagojr, DOAJ, Accreditation, Garuda, Sinta) and international level (indexed by Scopus).

The Human Resources sector, both lecturers and academic staff, has also undergone transformational management by the IIM Surakarta. The addition of lecturers is carried out by around $20 \%$ of the NIDN submission process to Kopertais, while the education staff is added up to $30 \%$. The addition also aims to prepare for the addition of the Bachelor Degree of Islamic Economics and Magister Program of Islamic Education study, which is currently at the proposal submission stage and is waiting for a visitation from the centre.

The changes also touch the operational management lines and academic services where working hours start every Monday to Friday from 08.00-16.00. As for the campus facilities and infrastructure sector. The reshuffle can be seen separating the IIM Surakarta management rooms where the leadership (rector and dean) and each faculty have their space. In addition, the lecturer rooms are also divided according to their respective faculties. Building construction and maximizing the use of existing buildings were also carried out, especially in preparation for opening new Bachelor Degree and Postgraduate programs at IIM Surakarta.

Furthermore, cooperation with international education is also a form of IIM's transformation management towards a world-class Islamic Institute. IIM Surakarta has collaborated with Hassan First University, Morocco and Fatoni University, Thailand. In addition, IIM is presently accepting students from Malaysia, which is a form of student exchange from other countries.

The online SIAKAD (Academic Information System) model of the Sevima GoFeeder model has also been applied to IIM Surakarta lecturers and students. This system is a form of academic administration transformation management in the institute environment, making it easier for the institution to submit reports to PDDIKTI. SIAKAD is an easy solution in maximizing online learning activities and improving campus services. Several features that lecturers must complete through SIAKAD are 1) online attendance, 2) lecturer teaching journals/teaching activity reports, 3) student test scores for both middle and final exams.

\section{Selection Strategies of IIM Surakarta Strategic Planning}

In choosing a strategy, the first and foremost thing that the IIM Surakarta campus applies is a SWOT (Strength, Weakness, Opportunity, Threat) analysis. Warlizasusi states that the study of strengths and weaknesses are internal strategic influences, while opportunities and threats are external strategic influences (Warlizasusi, 2018). By observing and considering strategic forces, various policy steps will be drawn up to achieve performance targets in the preparation of the Strategic Plan (Renstra) for educational institutions.

In selecting a strategy, the first and foremost thing that the IIM Surakarta applies is a SWOT (Strength, Weakness, Opportunity, and Threat) analysis. Warlizasusi states that analysing strengths and weaknesses are internal strategic influences (Warlizasusi, 2018). Meanwhile, opportunities and threats are external strategic influences. By observing and considering strategic forces, various policy steps will be drawn up to achieve performance targets in preparing the Strategic Plan for educational institutions. 
The SWOT analysis at IIM Surakarta is carried out in three areas, including 1) Academic \& Student Affairs, 2) Community Service, and 3) Leadership, Management Systems, Governance and Quality Assurance.

Table 1. Academic \& Student Affairs

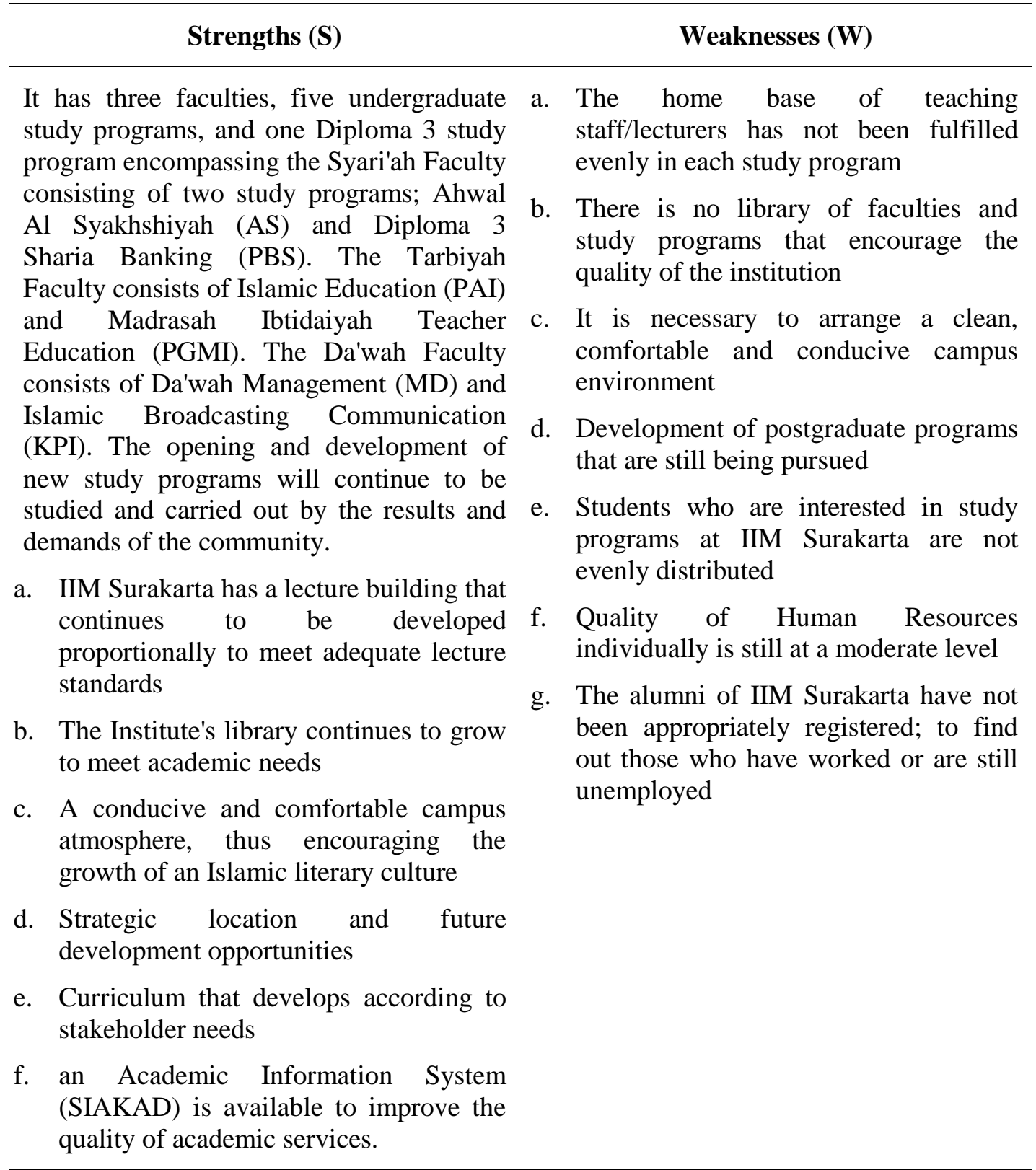

Opportunities (O)

Threats (T)

a. The role of institutions such as Ma'had in providing Islamic guidance and education to students as well as increasing the mastery of foreign languages (Arabic and English)

b. Having a code of ethics or student regulations governing IIM Surakarta students a. Changes and advances in globalization, especially in the field of information technology, have an impact on the mastery and use of technology for educational institutions

b. Government policies that are constantly changing, sometimes not according to the actual needs and social realities of 
c. On average, lecturers have Master and the people in Central Java

Doctoral qualifications;

Table 2. Community Sevice Sector

\section{Strengths (S) \\ Weaknesses (W)}

a. Every year the implementation of Community Service involving IIM Surakarta students improves and is relatively more organized and perfect.

b. Lecturers of IIM Surakarta have more opportunities to carry out community service independently.

c. Every lecturer can become a mentor in community service activities by students.

a. The Research Institute and community service have not yet optimally collaborated with regional governments in carrying out research and community service.

b. Students' community service activities have not had a long-term impact on the community in Surakarta and surrounding areas.

c. Community service activities by students have not implemented the PAR (Participation Action Research) system, which impacts the community on an ongoing basis.

d. Limited development funds for research and community service

a. Many fields of knowledge are opportunities for students and IIM Surakarta as a higher education institution in contributing to society.

b. More and more journals/articles/other writings are published as forums for scientific writings or lecturers' ideas, both on campus and in public.

c. We are opening opportunities to collaborate with other parties, both from higher education institutions and education parties.

Table 3. Leadership, Management System, Governance and Quality Assurance

\section{Strengths (S)}

\section{Weaknesses $(\mathbf{W})$}

There is a periodic evaluation for academic a. The quality and productivity of human activities within IIM Surakarta. resources are not sufficient

b. Management system, human resources (recruitment function, research and development, maintenance and use) are 


\begin{tabular}{cc}
\hline Opportunities $(\mathbf{O})$ & not well organized \\
\hline & \multicolumn{1}{c}{ Threats $(\mathbf{T})$} \\
\hline & $\begin{array}{l}\text { Changes in Government Regulations on the } \\
\text { management status of Higher Education. }\end{array}$ \\
\hline
\end{tabular}

The strategies applied by IIM Surakarta in strategic planning include:

\section{Strategic Objectives}

Strategic objectives are formulated by the Institute's vision, future challenges and a review of the existing resources and infrastructure at IIM. From 2020 to 2024, IIM is expected to be able to achieve the following strategic goals:

a. The best accreditation rating of the national accrediting agency may increase

b. The culture of research, community service and scientific publications may increase

c. The competitiveness of graduates at the local and national levels may increase

d. Educational study programs may increase

e. Local and national cooperation may increase

f. Good governance can be implemented well

\section{Basic Strategic}

To achieve the strategic goals, starting from self-evaluation and the achievements of the strategic plan for the previous year, and in general also paying attention to the direction of development policies, the basic strategy for developing IIM for the 20202024 period is set out below.

a. Conducting internal coalitions to prepare operational plans, intensive socialization of regulations and policies and coherence in the implementation of rules and policies

b. Strengthening the group in the ability section in the curriculum and learning quality assurance process and empowering educational staff as professionals

c. Strengthening research groups and community service to produce superior products and contribute to society

d. Providing cooperation facilities both nationally and internationally

\section{Strategies Pencapaian}

The achievement strategy for 4 (four) years of 2020-2024 are carried out based on 3 (three) stages encompassing:

a. The first stage (2020-2021) is a consolidation stage for strengthening governance by the statutes on improving the internal quality assurance system for empowerment, research, as well as improving agreements, and opening master study programs

b. The second stage (2022-2023) is improving the quality of accreditation and infrastructure 
c. The third stage (2024) is the expansion stage for research programs and international cooperation and the strengthening of academic access expansion programs.

\section{Strategy Implementation of Strategic Planning at IIM Surakarta}

Implementation of the strategy is an action and process where management implements procedures and policies in activities through setting goals and developing annual strategic programs, all of which support the methods that have been previously determined.

\section{Goal Setting}

Mamba'ul 'Ulum (IIM) of Surakarta has established the Institute's Strategic Plan for 2020-2024 with the following description of objectives:

a. It is building a civilized, pious and faithful person to Allah SWT, having an Indonesian spirit and academic skills that can develop, apply, and enrich science, technology, and art.

b. We are continuously improving the quality of IIM to achieve an honourable position in global collaboration and competition.

c. We are placing IIM as the foremost centre in education, research and community service for the nation's welfare while maintaining local wisdom.

2. Strategic Program

Strategic Program of IIM Surakarta includes:

a. Academic Management and Improving Student Insight

1) Establishment of the Magister of Islamic Education and Bachelor Degree of Islamic Economics

2) Study Program Reaccreditation

3) Revitalization of Quality Assurance

4) Strengthening Lecturer Competence

- Strengthening the Academic Atmosphere, Literacy and Student Insights

b. Empowerment of Lecturer Expertise in the Field of Research and Community Service

1) Revitalization of Research and Community Services Institute

2) Management of Lecturer Academic Product

3) Strengthening and Development of Human Resources and Restructuring Management at IIM Pengembangan SDM

4) Strengthening Human Resources

5) Decentralized Management with Strengthened Deans

c. Initiating, Mentoring and Fostering Student Talent Potential

1) Interests Talent Search

2) Interest Talent Management 
3) Optimization of Alumni Participation

d. Fulfilment and Maintenance of Campus Facilities and Infrastructure

1) Program of Campus Inventory

2) Program of Clean, Comfortable, and Islamic Campus

3) Space Fulfillment

e. Strengthening Campus Management Information System

1) Development of SIAKAD

2) Development of Mailing Services for Students

3) Student Digital Data Availability

4) Payment Service Development

f. Revitalization of Public Relations Cooperation and Campus Image

1) Revitalization of Public Relations and Campus Image

2) Strengthening the Cooperation Network

\section{CONCLUSION}

IIM Surakarta is transforming, so the institution can lead to the development of better Islamic tertiary institutions, growth in both quality and quantity. Management aspects of the transformation of IIM Surakarta to a World-Class Islamic Institute include 1) Planning, 2) Organizing, 3) Actuating and 4) Evaluating. These aspects will be applied to the institute and all study programs at IIM Surakarta. In selecting a strategy, the first and foremost thing that the IIM Surakarta uses is a SWOT analysis. This SWOT analysis was carried out in three areas, including a) Academic \& Student Affairs, b) Community Service, and c) Leadership, Management Systems, Governance and Quality Assurance. Implementation of IIM Surakarta's strategic planning includes setting goals and developing annual strategic programs.

Institutional transformation in higher education is related to the structure and mindset. Physical and mental readiness is an essential key to welcoming any changes. Thus, universities trying to improve their status must realize the importance of preparing themselves early to transform seriously. In this context, a strong leader is needed, namely someone who consistently focuses on overseeing the institution's transformation.

\section{REFERENCES}

[1] Anwar, S. (2021). Pendidikan Karakter: Kajian Perspektif Tafsir fi Zilalil Qur'an. Tulungagung: STAI Muhammadiyah Tulungagung.

[2] Chaer, M. T., Rochmah, E. Y., \& Sukatin. (2021). Education Based on Local Wisdom. JIE: Journal of Islamic Edication, 6(2), 145-157.

[3] Darma, A., \& Banurea, O. K. (2019). Peran Kepempimpinan Kepala Sekolah Dalam Manajemen Perubahan Di Lembaga Pendidikan. BENCHMARKING, 3(1), $1-18$. 
[4] Etistika Yuni Wijaya, Sudjimat, D. A., \& Nyoto, A. (2016). Transformasi Pendidikan Abad 21 Sebagai Tuntutan. Prosiding Seminar Nasional Pendidikan Matematika 2016 Universitas Kanjuruhan Malang |, 1, 263-278.

[5] Hassan, A. T. (2018). Organizational Change Management: A Literature Review. SSRN Electronic Journal. https://doi.org/10.2139/ssrn.3135770

[6] Hayes, J. (2018). The Theory and Practice of Change Management. London: Palgrave.

[7] Ikhwan, A. (2021). Metode Penelitian Dasar (Mengenal Model Penelitian dan Sistematikanya). Tulungagung: STAI Muhammadiyah Tulungagung.

[8] Ikhwan, A., Biantoro, O. F., \& Rohmad, A. (2019). The Role of the Family in Internalizing Islamic Values. Dinamika Ilmu. https://doi.org/10.21093/di.v19i2.1746

[9] Ilyasin, M. (2020). Transformation of Learning Management: Integrative Study of Islamic Boarding School Curriculum. Dinamika Ilmu, 20(1), 13-22. https://doi.org/10.21093/di.v20i1.2006

[10] Indrawan, R., \& Yaniawati, P. (2017). Metode Penelitian (3rd ed.). Bandung: PT. Refika Aditama.

[11] Johnson, R. E. (2019). Organizational Change Management.

[12] Levin, H. M., Jeong, D. W., \& Ou, D. (2006). What is World Class University? The 2006 Conference of the Comparative Annd International Education Society. Honolulu (Hawaii: The Conference of the Comparative Annd International Education Society), 32, 1-49.

[13] Mastuki, H. (2015). World Class-University: Obsesi atau Mimpi?

[14] Mawardi, I. (2017). Transformasi Lembaga Pendidikan Tinggi: Penguatan Kualitas Luaran SDM di Era Globalisasi. ADHITAKARYA: Jurnal Ilmiah Penelitian, Pengkajian Dan Pengembanga, (6), 1-12.

[15] Mufron, A. (2021). World Class University pada Perguruan Tinggi Keagamaan Islam: Kebijakan dan Strategi Transformasi. Transformasi: Jurnal Studi Agama Islam, 14(1), 1-16.

[16] Mufron, Ali, Ikhwan, A., Syuhada, M., \& Ridlowi, A. (2021). Optimizing the Organizational Structure in Transforming Human Resources Who Can Manage Work Stress With a Religious Culture. European Journal of Molecular \& Clinical Medicine, 8(3), 1110-1126.

[17] Sukmadinata, N, S. (2020). Metode Penelitian Penddikan (13th ed.). Bandung: Remaja Rosdakarya.

[18] Syahrul. (2016). Readiness Frame: Analisis Kerangka Kesiapan dalam Transformasi Pendidikan Tinggi (Pengalaman IAIN Kendari). AL TA 'DIB: Jurnal Kajian Ilmu Pendidikan, 9(1), 162-180.

[19] Warlizasusi, J. (2018). Analisis Perencanaan Strategis, Rencana Strategis dan Manajemen Strategis STAIN Curup 2015-2019. Tadbir: Jurnal Studi Manajemen Pendidikan, 2(2), 155. https://doi.org/10.29240/jsmp.v2i2.664 